\title{
SOSIALISASI TENTANG PENGGUNAAN MEDIA SOSIAL YANG CERDAS DAN BERETIKA
}

\author{
Triwanto, Esti Aryani \\ Fakultas Hukum Universitas Slamet Riyadi Surakarta
}

\begin{tabular}{l}
\hline Info Artikel \\
Masuk: Maret 2020 \\
Revisi: Mei 2020 \\
Diterima:Juli 2020 \\
Terbit: Agustus 2020 \\
Keywords: \\
social media, ethics, law \\
Kata kunci: \\
media sosial, etika, hukum \\
P-ISSN: 2598-2273 \\
E-ISSN: 2598-2281
\end{tabular}

\begin{abstract}
Abstrak
The use of social media today cannot be stopped anymore along with the development of information and communication technology. It is undeniable that social media is also widely used by mothers. The use of social media wisely will be very beneficial for its users. Therefore, it is important for the public to be given knowledge that the use of social media that is wrong can have adverse consequences and can even deal with the law.
\end{abstract}

\section{PENDAHULUAN}

\begin{tabular}{l}
\hline Abstrak \\
\hline Penggunaan media sosial dewasa ini tidak dapat dibendung lagi \\
seiring dengan perkembangan teknologi informasi dan \\
komunikasi. Tidak dapat dipungkiri media sosial juga banyak \\
digunakan oleh kaum ibu. Penggunaan media sosial secara bijak \\
akan sangat bermanfaat bagi penggunanya. Oleh karena itu \\
kepada masyarakat perlu diberikan pengetahuan bahwa \\
penggunaan media sosial yang keliru dapat berakibat yang \\
merugikan bahkan dapat berurusan dengan hukum.
\end{tabular}

Perkembangan teknologi dewasa ini sedemikian pesat, komunikasi menjadi salah satu kebutuhan pokok. Salah satu cara berkomunikasi yang sangat populer adalah melalui media sosial. Media sosial menjadi kebutuhan penting bagi banyak orang. Tak jarang kita selalu terhubung dengan dunia luar melalui media sosial. Hubungan beragam yang dibangun dengan orang yang sudah dikenal, kerabat, relasi, ataupun pihak-pihak yang belum kita kenal dan baru diketahui lewat dunia maya.

Menurut C. Widyo Hermawan, adanya penggunaan internet melalui media sosial, telah menghadirkan sebuah web forum yang dapat membentuk suatu komunitas online( Hermawan CW, 2009 )Layaknya forum diskusi, sebuah web forum dapat juga menampung ide, pendapat, dan segala informasi dari para anggotanya sehingga dapat saling berkomunikasi atau bertukar pikiran antara satu sama lainnya. 
Sebuah forum online biasanya hanya memiliki suatu pokok bahasan tertentu, tetapi tidak menutup kemungkinan dapat meluas hingga ke berbagai bidang.

Media sosial beragam mulai bermunculan dan menjadi pilihan masyarakat, seperti facebook, twitter, instagram, path, Whatsapp dan masih banyak lainnya. Interaksi yang dilakukan dalam media sosial, haruslah memperhatikan etika dalam berinteraksi. Hal ini sangat penting agar segala aktivitas kita di media sosial tidak berdampak buruk dalam kehidupan kita, baik secara langsung maupun tidak langsung.

Masyarakat sebagai pengguna media sosial harus menjadi pengguna yang cerdas yang mematuhi etika dan aturan hukum yang berlaku. Di Indonesia penggunaan internet sebagai sarana komunikasi diatur dengan Undang-Undang yaitu UU RI Nomor 19 Tahun 2016 Tentang Perubahan Atas UU Nomor 11 Tahun 2008 Tentang Informasi dan Transaksi Elektronik.

UU No 11 Tahun 2008 Tentang Informasi dan Transaksi Elektronik mengatur tentang asas dan tujuan pemanfaatan teknologi. Pasal 3 mengatur bahwa pemanfaatan teknologi informasi dan transaksi elektronik dilaksanakan berdasarkan asas kepastian hukum, asas manfaat, kehati-hatian, itikad baik dan kebebasan memilih teknologi atau netral teknologi.

Pemanfaatan teknologi informasi dan transaksi elektronik dilaksanakan dengan tujuan untuk :

1. mencerdaskan kehidupan bangsa sebagai bagian dari masyarakat informasi dunia,

2. mengembangkan perdagangan dan perekonomian nasional dalam rangka meningkatkan kesejahteraan masyarakat,

3. meningkatkan efektivitas dan efisiensi pelayanan publik.

4. membuka kesempatan seluas-luasnya kepada setiap orang untuk memajukan pemikiran dan kemampuan dibidang penggunaan dan pemanfaatan teknologi informasi seoptimal mungkin dan bertanggung jawab,

5. memberikan rasa aman, keadilan, dan kepastian hukum bagi pengguna dan penyelenggara teknologi informasi.

UU ITE mengatur perbuatan apa saja yang dilarang di beberapa pasal yaitu Pasal 27 sampai dengan Pasal 37 yang secara ringkas dapat dirinci bebagai berikut: 
1. Dilarang dengan sengaja membuat atau menyebarkan informasi yang bermuatan :
a. asusila
b. perjudian
c. penghinaan
d. pencemaran nama baik
e. pemerasan
f. pengancaman kekerasan, menakut-nakuti
g. berita bohong
h. informasi menyesatkan yang mengakibatkan kerugian konsumen.
i. cyber bullying

2. Dilarang mengakses sistem elektronik milik orang lain.

3. Dilarang mengakses sistem elektronik milik orang lain, dengan tujuan untuk memperoleh informasi.

4. Dilarang mengakses sistem elektronik milik orang lain, dengan cara melanggar, menerobos, melampaui, atau menjebol sistem keamanan.

5. Dilarang melakukan penyadapan atas informasi dalam komputer milik orang lain, kecuali dilakukan oleh pihak khusus dengan ijin khusus seperti untuk upaya penegakan hukum.

6. Dilarang melakukan penyadapan transmisi elektronik yang bersifat privat, baik sifatnya hanya melakukan penyadapan, melakukan perubahan informasi, melakukan penghilangan informasi, melakukan penghentian informasi, kecuali dilakukan oleh pihak khusus dengan ijin khusus seperti untuk upaya penegakan hukum. Yang dimaksud dengan penyadapan adalah kegiatan untuk mendengarkan, merekam, membelokkan, mengubah, menghambat, mencatat terhadap pengiriman informasi elektronik yang bersifat privat.

7. Dilarang mengubah, menambah, mengurangi, menyebarkan, merusak, menghilangkan, memindahkan, menyembunyikan informasi elektronik milik orang lain atau milik publik.

8. Dilarang memindahkan atau mengirimkan informasi elektronik kepada sistem elektronik orang lain yang tidak berhak. 
9. Dilarang melakukan aktivitas untuk mengganggu sistem elektronik yang mengakibatkan sistem elektronik tidak bekerja sebagaimana mestinya.

10. Dilarang membuka informasi elektronik yang bersifat rahasia menjadi dapat diakses publik.

11. Dilarang dengan sengaja memproduksi, menjual, mengadakan, mengimpor, mendistribusikan, menyediakan, memiliki perangkat keras atau perangkat lunak yang dirancang secara khusus untuk memfasilitasi perbuatan perbuatan yang dilarang pada poin sebelumnya, dengan pengecualian hal tersebut tidak dilarang jika perangkat ini digunakan untuk kegiatan penelitian, pengujian sistem, atau upaya perlindungan sistem elektronik.

12. Dilarang memanipulasi, menciptakan, merubah, menghilangkan, merusak informasi elektronik dengan tujuan agar informasi tersebut dianggap seolaholah data yang otentik.

13. Dilarang melakukan perbuatan - perbuatan terlarang yang telah disebutkan pada poin - poin di atas dari luar wilayah Indonesia terhadap sistem elektronik yang berada di wilayah Indonesia.

\section{METODE PELAKSANAAN}

Kegiatan penyuluhan hukum dalam rangka pengabdian kepada masyarakat dilaksanakan di Desa Plesungan, Gondangrejo, Karanganyar pada hari Kamis Jumat tanggal 17 - 18 Oktober 2019 bertempat di Balai Desa Plesungan. Kegiatan dilakukan dalam bentuk ceramah dan diskusi.

\section{PEMBAHASAN}

Kegiatan penyuluhan hukum yang dilaksanakan di Desa Plesungan dengan peserta ibu - ibu anggota PKK berjalan dengan baik dan menyenangkan. Para peserta antusias untuk mengetahui dan memahami materi yang disampaikan. Hal ini sangat mendukung tersampaikannya materi dengan baik kepada peserta. Adapun hasil yang dicapai adalah para peserta mendapatkan pengetahuan bahwa menggunakan media sosial ada aturan hukumnya dan ada etikanya sehingga para peserta dapat lebih bijak ketika hendak menggunggah maupun membagikan sebuah konten ataupun postingan. 
Pengabdian Masyarakat merupakan kegiatan wajib bagi dosen sebagai pelaksanaan Tri Dharma Perguruan Tinggi, oleh karenanya ke depan kegiatan ini akan terus dilaksanakan di semua kalangan masyarakat baik kelompok ibu - ibu maupun warga desa dan pemuda - pemudi. Kegiatan penyuluhan hukum ini juga hendak melibatkan dan bekerja sama dengan berbagai instansi sesuai materi yang hendak disampaikan. Penggunaan media sosial dewasa ini tidak dapat dibendung lagi seiring dengan perkembangan teknologi informasi dan komunikasi. Tidak dapat dipungkiri media sosial juga banyak digunakan oleh kaum ibu. Penggunaan media sosial secara bijak akan sangat bermanfaat bagi penggunanya. Oleh karena itu kepada masyarakat perlu diberikan pengetahuan bahwa penggunaan media sosial yang keliru dapat berakibat yang merugikan bahkan dapat berurusan dengan hukum.

Hendaknya penyuluhan hukum tentang penggunaan media sosial dan aturan hukumnya terus dilakukan di semua kalangan masyarakat baik kaum ibu, bapak maupun kaum muda dan remaja.

\section{DAFTAR PUSTAKA}

Hermawan, C. W. (2009). Cara Mudah Membuat Komunitas Online dengan PHPBB.

Yogyakarta: ANDI.

UU Nomor 11 Tahun 2008 Tentang Informasi dan Transaksi Elektronik.

UU RI Nomor 19 Tahun 2016 Tentang Perubahan Atas UU Nomor 11 Tahun 2008

Tentang Informasi dan Transaksi Elektronik. 